\title{
THE IMPACT OF LEADERSHIP, CREATIVITY, AND INNOVATION ON COMPETITIVE ADVANTAGE: PROPOSING A COMPREHENSIVE FRAMEWORK FOR A BETTER INDONESIA
}

\author{
Hendry Hartono \\ Management Department, School of Business Management, BINUS University \\ Jln. K. H. Syahdan No. 9, Palmerah, Jakarta Barat 11480 \\ hhartono@binus.edu
}

\begin{abstract}
This paper contributes to the existing literature by exploring the relationship of creativity, leadership, and innovation on competitive advantage; and explores the connection between creativity, leadership, and innovation. Research used literature review method as a systematic search of published works to find out what is already known about the intended research. Every company that wants to survive in the global market must have vehicles, like creativity and innovation. Beside, managing effectively to create sustainable competitive advantage needs leadership because leaders are central to the process of creating culture, systems, and structure that foster creativity and innovation.
\end{abstract}

Keywords: leadership, creativity, innovation, competitive advantage, entrepreneurship

\begin{abstract}
ABSTRAK
Artikel memberikan kontribusi terhadap literatur yang ada dengan mencari hubungan kreativitas, kepemimpinan, dan inovasi terhadap keunggulan kompetitif; dan menggali hubungan antara kreativitas, kepemimpinan, dan inovasi. Penelitian menggunakan metode tinjauan literatur sebagai penelusuran sistematis karya yang dipublikasi untuk mencari tahu hal yang sudah diketahui tentang penelitian dimaksud. Setiap perusahaan yang ingin bertahan di pasar global harus memiliki kendaraan seperti kreativitas dan inovasi. Di samping itu, pengelolaan secara efektif untuk menciptakan keunggulan kompetitif yang berkelanjutan membutuhkan kepemimpinan karena pemimpin penting bagi proses penciptaan budaya, system, dan struktur yang mendorong kreativitas dan inovasi.
\end{abstract}

Kata kunci: kepemimpinan, kreativitas, inovasi, keunggulan kompetitif, kewirausahaan 


\section{INTRODUCTION}

Sociologist David McClelland argued: "A country can be prosperous if any entrepreneur at least $2 \%$ of the population." Indonesia is a country of nearly 250 million people-has just had 400,000 entrepreneurs who build scalable, innovative companies. That's less than $1 \%$ of the population, compared to $13 \%$ for the United States and $7 \%$ for nearby Singapore. The question is why the growth of entrepreneurs in Indonesia is still far from expectations.

To compete with global competition, most of entrepreneurs need to constantly improve their existing products and services through continuous changes of innovation needed; and for survival of the company, they must also need to create new products and services to meet yet unfilled needs. Changes are very important to all successful leaders of the future that really need to improve their creativity, leadership, and innovation as a strategic priority in their organization. In today's environment where competition environment requires company to be distinct and meet customer need, which are with better products and services. Joseph Schumpeter argues that innovations are as the source of success in the global economy, a view that is reinforced by existing competitive environment, and rapidly changing environment. This means that company thus are not innovative cannot survive in the market place and remain the relevant of every business purposes to satisfy the customer needs.

This paper contributes to the existing literature by exploring the relationship of creativity, leadership, and innovation on competitive advantage. This paper builds on the knowledge-based view as a foundation for understanding why creativity, leadership, and innovation create competitive advantages, and then explores the connection between creativity, leadership, and innovation and suggest the comprehensive framework to answer this paper main purpose.

\section{Literature Review}

\section{Creativity}

Creativity is marked by the ability to create, to bring into existence, to invent into a new form, to produce through imaginative skill, to make to bring into existence something new. Creativity is not ability to create out of nothing, but the ability to generate new ideas by combining, changing, or reapplying existing ideas. Some creative ideas are astonishing and brilliant, while others are just simple, good practical ideas that no one seems to have thought, of yet (Harris, 1998). Everyone has substantial creative ability. Creativity is also an attitude, the ability to accept change and newness, a willingness to play with ideas and possibilities, a flexibility of outlook, the habit of enjoying the good, while looking for ways to improve it, we are socialized into accepting only a small number of permissible or normal things, like chocolate-covered strawberries, for example. The creative person realizes that there are other possibilities like peanut butter and banana sandwiches, or chocolatecovered prunes (Harris, 1998). Creativity is also a process. Creative persons work hard and continually to improve ideas and solutions, by making gradual alterations and refinements to their works. Contrary to the mythology surrounding creativity, very few of creative excellence are produced with a single stroke of brilliance or in a frenzy of rapid activity. Much closer to the real truth are the stories of companies which had to take the invention away from the inventor in order to market it because the inventor would have kept on tweaking it and fiddling with it, always trying to make it a little better (Harris, 1998). A product is creative when it is "novel" and "appropriate". A novel product is original, not predicable. The bigger the concept, the more the product stimulates further work ideals, the more the product is creative. Creativity requires passion and commitment. Out of the creative is born symbols and myths. It brings to our awareness of what was previously hidden and points to new life. 
Creativity is an individual and cultural phenomenon that allows us to transform possibilities into reality (Sternberg, 1997), the individual's ability and capacity to create and develop new, novel and useful ideas about firm's products, practices, services or procedure (Kaylar, 2011) is also creativity. When the ideas generated in creativity are successfully implemented, it becomes innovation. Creative theorists have argued that individual's creativity is an important antecedent and precondition for innovation. Creativity has been suggested as important and key antecedent factor for individual innovation (Kaylar, 2011). An individual group member having higher ability to generate new, novel and useful ideas is more likely to create own innovation (Woodman, et al., 1993), which in turn contributes to group and organizational innovation. On theoretical grounds, it is inferred that ability to create and developing new and useful ideas increases the likelihood of creating innovation. Creativity requires absolute novelty of the idea whereas innovation only requires relative novelty of the idea to the unit of adoption (Woodman, et al., 1993). Therefore, adopting a new policy from another organization to the current organization would be innovative but not creative. The definition of creativity also includes an essential requirement for the idea or product to be useful. Theory suggests positive relationship between creativity and innovation.

\section{Leadership}

Leadership is defined as a process of influencing or leading oneself through the use of specific sets of behavioral and cognitive strategies. Behavioral strategies include encouraging the positive, desirable behaviors that lead to successful outcomes, while suppressing the negative, undesirable behaviors that lead to an unsuccessful outcome. Cognitive strategies comprise of creating feelings of self-determination and development of constructive thoughts such as positive self-talk. Leadership theorists have proposed that creativity and innovation are the anticipated outcomes of individual leadership (Kaylar, 2006). However, research on the relationship between leadership, creativity, and innovation is still at the nascent stage. An additional research is needed to further clarify the relationship between leadership, creativity, and innovation. Furthermore, it is evident that the leadership skill is a significant antecedent factor that positively affects innovative behavior. Hence, given leadership's conceptualization as a determinant of innovation, leadership is expected to have direct effect on innovation of group members (Kaylar, 2011). Creativity alone is not sufficient for developing an innovation. Individuals must also have a definite level of internal force that pushes them to proceed in facing the challenges in creative work. Leadership is necessary in those organizations that need continuous innovation. When employees are encouraged to lead themselves in defining problems, solving problems, making decision, and identifying opportunities and challenges both now and in the future, their creativity is encouraged. On the other hand, if employees are not encouraged to lead themselves in critical situations, then creativity is not encouraged.

\section{Trust}

Trust is based on evaluations of integrity, competence, commitment to one another, consistency, and openness regardless of whether the relationship is between oneself and a supervisor, a subordinate, or a peer (Ruppel and Harington, 2000). Thus trust is based on perception of prior performance or reputation. Literature also suggests that such trust leads to the smooth, and effective functioning of organizations, more efficient problem-solving and the consideration of a wider range of solution, since decision maker need not protect themselves from opportunistic behavior. Trust is critical to the evolution of employee commitment in times of change or innovation.

\section{Innovation}

Innovation is the process of bringing the best ideas into reality, which triggers a creative idea, which generates a series of innovative events. Innovation is the creation of new value. Innovation is the process that transforms new ideas into new value- turning an idea into value. You cannot innovate without creativity. Innovation is the process that combines ideas and knowledge into new value. 
Without innovation an enterprise and what it provides quickly become obsolete. The dictionary defines innovation as the introduction of something new or different. Innovation is the implementation of creative inspiration. Literature (et. all) defines innovation as "the inter-section of invention and insight, leading to the creative of social and economic value" Innovation is "value" - the creation of value adding value to customer's satisfaction- "delighting the customers". Innovation is the basis of all competition advantages, the means of anticipating and meeting customer's needs and the method of utilization of technology. Innovation is fostered by information gathered from new connections; from insights gained by journeys into other disciplines or places; from active, collegial networks and fluid open boundaries. Innovation arises from organizing circles of exchange, where information is not just accumulated or stored, but created. Knowledge is generated a new from connections that were not there before. Innovation requires a fresh way of looking at things, an understanding of people, and an entrepreneurial willingness to take risks and to work hard. An idea doesn't become an innovation until it is widely adopted and incorporated into people's daily lives. Most people resist change, so a key part of innovating is convincing other people that your idea is a good one - by enlisting their help, and, in doing so, by helping them see the usefulness of the idea- Art Fry. Enterprises throughout the world are experiencing what can be legitimately described as a revolution: rising energy and material costs, fierce international competition, new technologies, increasing use of automation and computers.

All these are major challenges, which demand a positive response from the entrepreneur and management if the enterprise is to survive and prosper. At a time when finance is expensive, the firm's liquidity is bordering on crisis, the need for creativity, and innovation is more pressing than ever and as competitors fall by the way side, the rewards for successful products and process are greater. The instigation of new development is the responsibility of the enterprises themselves, which, through experience, are aware of the difficulties created when undertaking innovative investments in a period of great uncertainty. Innovation calls for special entrepreneurial and management skills, the cooperation of a committed workforce, finance and a climate which will create the optimum overall conditions to encourage success. Joseph Schumpeter (1934) believes that the concept of innovation, described as the use of an invention to create a new commercial product or service, is the key force in creating new demand and thus new wealth. Innovation creates new demand and entrepreneurs bring the innovations to the market. This destroys the existing markets and creates new ones, which will in turn be destroyed by even newer products or services. Schumpeter calls this process "creative destructions."

Innovation allows organizations to progress parallel with the changes flourishing in the environment. Innovation is a strategic key in responding to the new challenges of an environment full of uncertainties (Montes et al., 2003). For an organization, innovation would denote the generation or adoption of novel ideas or behavior. In the literature the idea that innovation is essential for firms' long-term success and survival constituting a competitive instrument is widely recognized. Reflect on that definition, author suggestions as organizations fit to the changing conditions of the technology and the market by diversifying and adapting, through innovation. Montes defines innovation as the adoption of an internally generated or purchased device, system, policy, program, process, product, or service that is not necessarily new to the world but specifically new for that adopting organization. Wu, et al (2008) suggested that innovation is defined as an idea, a product or process, or a system that is perceived to be new to an individual.

Innovation is a strategic option for improving the organization and making it more competitive. As it is referred to the study of Hitt, et al. (1997) and Tidd (2001), innovation is defined as the doors opening to both global and international competitive advantage through: providing the marketplace with new or unique products/services; creating entry barriers that provide the necessary resources to develop innovation through learning; and creating new values that reshape the rules of competitive environment (Montes et al., 2005). 
Innovation capabilities in individuals at workplace are significant characteristics that help an organization to establish competitive advantages in strategic competition and in ever changing environment. Individual innovation provides an organization foundation for high performance. It also enables an organization to improve its competitiveness and promote long-term success. Innovation has been defined as the successful implementation of creative ideas within an organization. Individual innovation is defined as innovation at individual level or creativity, exploitation and implementation of new and useful products and procedures by individuals.

Innovation is very important, especially for companies that produce technology-driven products, with the risk of technological obsolescence and in environments characterized by competitive intensity, technological and market dynamism. Organizations around the globe are encountering a joint challenge that is the need to improve the performance to capitalize on rapid change, and to establish or recapture competitive advantage to ensure their survival, profitability and successful running in dynamic competitive environment. Innovativeness of firms and organizations depends on internal factors such as the firm's innovative capability, size and structure, learning orientation, and strategic orientation and external factors such as network of partners, external communication and the industrial environment in which the company is located.

Innovation is a complex process and it arises from linkages between multiple sources rather from a single and individual source. When employees produce new, novel and useful products or procedures, they are basically providing the organization with options. Employee's innovation allows an organization to choose from a broader array of products or procedures for development and later implementation. Most existing research into innovation has focused at the firm level and few studies have directly tested the intermediate processes through which individual and contextual factors affect individual innovation, research in this area in Asia Pacific is still in nascent stage. The lack of research in this area confines understanding of exactly how and why individual differences and contextual factors are affecting individual innovation. No evident could be found regarding research work in this area in South Asia region particularly in context of Indonesia. The practical innovation among Indonesian firms and innovators is therefore an important mechanism for developing, improving and sustaining the competitive advantage for not only ensuring firm's survival but also firm's success and capturing market share. These are individuals whose innovation and creativity provides foundation for high-performance and firm's competitiveness. In short, individual innovation appears at individual level and mainly responsible for generation of new, novel and useful ideas. Moreover, individual innovation belongs to a general construct of high abilities including creativity. Several scholars suggested that creativity and leadership are important antecedents of individual innovation. Creative theorists have argued that individual's creativity is an important antecedent and precondition for innovation. The higher ability of individuals to generate new, novel and useful ideas is more likely to create his/her own innovation, which in turn contributes to group and organizational innovation. Creativity alone is not sufficient for developing an innovation. Individuals must also have a certain level of inner force that enables them facing the challenges in creativity. This internal force comes from leadership which is the skill that fosters individual innovation. Leadership is a primary factor that participates and facilitates creativity and individual innovation. Previous literature also proposed that individual creativity and leadership can be increased in the risk taking supported culture. It was suggested that high congruence between a creative person and culture may result in high level of innovative performance. The relationships among above variables have been theoretically suggested (Pratoom \& Savatsomboon, 2010). On the basis of above discussion, the following hypothesized conceptual model is developed to analyze the correlation and effect of individual and group level factors on innovation of Indonesian producers group members. 


\section{Competitive Advantage}

Competitive advantage is mainly used to differentiate company performance in the profitmaking sector. It is a concept that means much more than the financial performance and shareholder value; these are both a measurement at a moment in time, usually short-term. Hence the value of the firm that is generated through the intangible assets and more specifically through the IC carries more importance than financial profit. An independent consultant, Freeman (2001) gave rise to the issue, how to gain competitive advantage for organizations by presenting the ideas of Professor Michael E. Porter from Harvard Business School. He explains that there are two basic types of competitive advantage: cost leadership and differentiation. The main factors that may lead to these two types of competitive advantage are sustained revenue, innovation and new product development, brand and reputation, employee relations, acquisitions and mergers (Freeman, 2001). Mentioned by Porter, the differentiation is an essential aspect in the owning of competitive advantage (Freeman, 2001). There is an extensive literature that examines various enterprise-specific factors involved in creating a position of competitive advantage for the firm, and the complex interplay between the firm's internal organizational factors and environmental factors. Research evidence suggests that while environmental contexts can be influential, they do not necessarily outweigh key internal factors that can be directly influenced by the enterprise (Hoffman, et al., 2006). Parallel to the influence of innovation on competitive advantage, innovation is the most important determinant of firm performance (Calantone, et al, 2003). Innovation advantage provides firms to serve their customers with most up-to date and innovative products and services with high quality as well as superior value (Zhou et al., 2009). Innovation is gaining importance as a major competitive and performance improver weapon for many organizations (Porter, 1990). Recently, knowledge-sharing with suppliers has received increasing research attention (Huang and Chang, 2008). Manufacturers have discovered the managerial, technological, and financial benefits that may accrue as a result of close ties with suppliers. Scholars also agree that a substantial part of the innovation process occurs between buyers and sellers in the supply chain (Huang and Chang, 2008). These advantages can be long lasting if the resource in question is rare, inimitable, and non-substitutable (Hoffmann et al, 2006). If the position that resource provides is more difficult for other competitors to catch up then it means that the organization succeeded to add the quality of longevity to that resource. The capability of innovating is a possible way of creating such a resource. Innovation is not imitable, once imitated it turns out to be not new anymore, it is rare because not every organization can result its research with a radical or incremental innovation and its non-substitutable because it is hard to compensate (Hoffmann et al, 2006).

\section{METHODS}

The research methods used literature review as a systematic search of published works to find out what is already known about the intended research. A literature review allows the researcher to find out what has been done in terms of the problem that is being investigated and to ensure that duplication does not occur. Literature review used in this paper is not only to identify and analyze all information written about a topic, but also to gain any insight and to understand the problem investigated.

\section{Conceptual Framework}

On the basis of above discussion, the following hypothesized conceptual model is developed to analyze the correlation and effect of creativity, leadership, and innovation on competitive advantage (Figure 1). 
Figure 1 Impact of Creativity, Leadership, and Innovation on Competitive Advantage

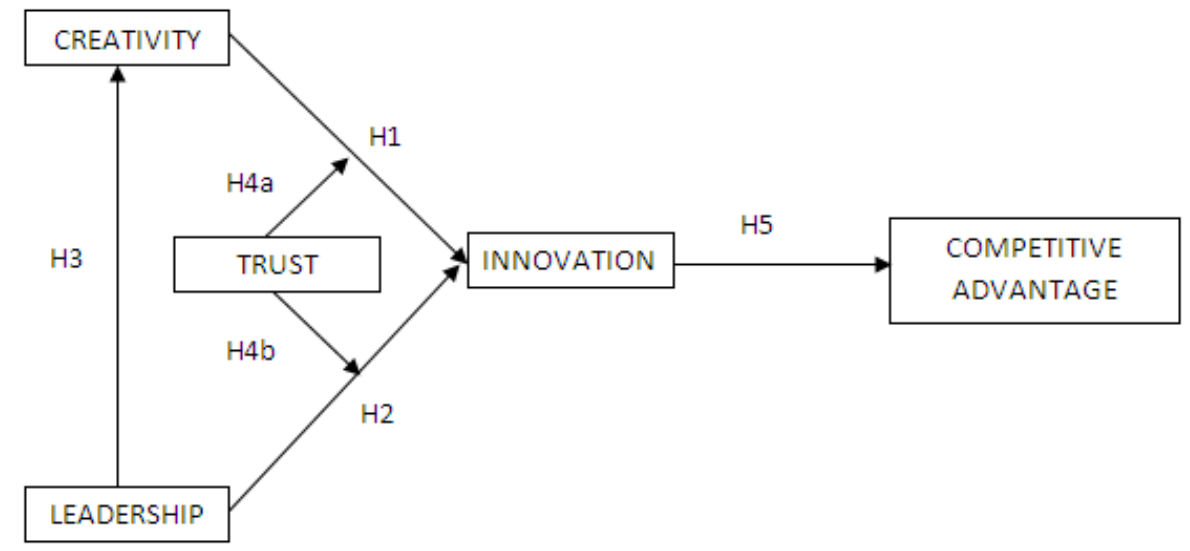

\section{DISCUSSION}

Individual innovation provides an organization foundation for high performance. It also enables an organization to improve its competitiveness. Innovation has been defined as the successful implementation of creative ides within an organization. Much of the popular literature, as well as some academic literature, stresses the importance of an innovative climate to the success of an organization. In addition, the organization should sense of trust that impact the adoption of some technological innovations. Innovation is very important, especially for organizations that produce technology-driven products, with the risk of technological obsolescence and in environment characterized by competitive intensity, technology, and market dynamism.

Creativity and leadership suggested by several scholars that are important antecedents of innovation, but many scholars have argued that creativity is an important antecedent for innovation. Innovation is a strategic option for improving the organization and making it more competitive. As it is referred to the study of Hitt, et al (1997) and Tidd (2001), innovation is defined as the doors opening to both global and international competitive advantage through providing the marketplace with new or unique products/services, creating entry barriers that provide the necessary resources to develop innovation through learning, and creating new values that reshape the rules of competitive environment (Montes, et al, 2005).

Competition in competitive environment is forcing many companies to accumulate intellectual assets and to use them effectively for the purpose of producing profitable operations. On the opposite of other primary resources, knowledge does not diminish as it is used, instead it gets depth as it is used and shared. Knowledge intensive firms rely on the management of the knowledge which will be adding value to the knowledge workers, products, and interactions. This stresses the importance of innovation as a driving factor on competitive advantage.

Creativity and Innovation are at the heart of the spirit of enterprise. It means striving to perform activities differently or to perform different activities to enable the entrepreneur deliver a unique mix of value. Thus the value of creativity and innovation is to provide a gateway for astute entrepreneurship-actively searching for opportunities to do new things, to do existing things in extraordinary ways. Creativity and Innovation therefore, trigger and propel first-rate entrepreneurship in steering organization activities in whatever new directions are dictated by market conditions and customer preferences, 
There by delighting the customers to the benefit of the stakeholders. Innovation also means anticipating the needs of the market, offering additional quality or services, organization efficiently, mastering details, and keeping cost under control. No doubt, the current economic environment is a volatile and violent one. The new environment demands renewed dynamism of approach. Creativity and innovation is the new name of the game. Only the discerning organizations can manage the changes inherent in the new environment. It is the duty of the entrepreneur to keep his/her organization lean, young, flexible, and eager for new things to continuously delight the customers, which is the purpose of every business.

$\begin{array}{ll}\text { H1 } & \text { : Creativity positively impacts innovation } \\ \text { H2 } & \text { : Leadership positively impacts innovation } \\ \text { H3 } & \text { : Leadership positively impacts creativity } \\ \text { H4a } & \text { : Trust positively intervening creativity through innovation } \\ \text { H4b } & \text { : Trust positively intervening leadership through innovation } \\ \text { H5 } & \text { : Innovation positively impacts Competitive Advantage }\end{array}$

There are several implications for creating competitive advantage. First, manager with leadership culture or skill competencies can make their organization more effective and foster creation of competitive advantage by creating trust among member of organization. Second, organizations that are able to foster their innovative products or services will create sustainable competitive advantage.

\section{CONCLUSION}

The main purpose of this study is to answer why the growth of entrepreneurs in Indonesia is still far from expectations. This paper has explored the relationship between creativity, leadership and innovation on competitive advantage and developed a suggested framework how important creativity, leadership, and innovation are in increasing competitive advantages of Indonesian's entrepreneurs; in the following improved their capabilities to compete with global environment. There is no doubt to survive in the global market, every company that wants to survive must have vehicles like creativity and innovation. Nevertheless, managing effectively to create sustainable competitive advantage needs leadership because leaders are central to the process of creating culture, systems and structure that foster creativity and innovation.

\section{REFERENCES}

Freeman, O. (2001). Does your organization use knowledge to gain competitive advantage? Business Information Review, Vol.3, pp.38-45.

Harris, R. (1998). Introduction to Creative Thinking. Accessed March 112013 from http://www.virtualsalt.com/crebook1.htm.

Hitt, M. A., Ireland, R. D. and Hosisson, R. E. (2001). Strategic Management: Competitiveness and Globalization. $4^{\text {th }}$ Edition. South Western.

Hoffman, J., Hoelscher, M., and Sorenson, R. (2006). Achieving Sustained Competitive Advantage: A Family Capital Theory. Family Business Review. Vol.19, No.2, pp.135-145. 
Huang, H.C., and Chang, C.W. (2008). Embedded ties and the acquisition of competitive advantage, Journal of Intellectual Capital, Vol. 9, No.1, pp.105-121.

Kaylar, M. N. (2010). Creativity, Self-leadership and Individual Innovation. The Journal of Commerce, 10(1), 20-28.

Montes, F. J., Moreno, A. R., Molina, L. M. (2003). An analysis of the relationship between quality and perceived innovation: the case of financial firms. Industrial Management + Data Systems 103, 8/9, 579-590.

Pratoom, K., and Savatsomboon, G. (2010). Explaining factors affecting individual innovation: The case of producer group members in Thailand. Asia Pacific Journal of Management.

Ruppel, C. P., and Harrington, S. J. (2000). The Relationship of Communication, Ethical Work Climate, and Trust to Commitment and Innovation. Journal of Business Ethics, 24 (4), 313328

Sternberg, R. J. (ed.). (1999). Handbook of Creativity. New York: Cambridge University.

Woodman, R., Sawyer, J., and Griffin, R. (1993). Toward a theory of organizational creativity. Academy of Management Review, 18(2), 293-321.

Wu, Y. W., Chang, M. L., and Chen, C. W. (2006). Promoting innovation through the accumulation of intellectual capital, social capital, and entrepreneurial orientation. R\&D Management, Vol.38, No.3, pp.265-277. 